\title{
Life history and production of three amphipod species on Georges Bank
}

\author{
Jeremy S. Collie \\ Woods Hole Oceanographic Institution, Woods Hole, Massachusetts 02543, USA
}

\begin{abstract}
As part of the Georges Bank Benthic Monitoring Program, size-frequency analysis was used to study the life history and production of 3 benthic amphipod species: Ampelisca agassizi, Unciola inermis and Ericthonius fasciatus. Abundant over large areas of Georges Bank, these amphipods are important prey of yellowtail flounder. From benthic grab samples collected quarterly during 1981 to 1983 , over 200 individuals of each species were measured from each sampling date. The computer program NORMSEP was used to separate the length-frequency distributions into cohorts. Growth and mortality rates were determined by following cohorts through time; production was calculated as the sum of growth increments. Differences in the population dynamics of the 3 species are exemplified by the annual production-to-biomass ratios. E. fasciatus has the highest $\mathrm{P} / \mathrm{B}$ ratio (4.4), followed by $U$. inermis (2.5) and $A$. agassizi (1.5). These results, the first direct production estimates far benthic macrofaunal species on Georges Bank, are compared to production estimates for other marine amphipod species. Amphipod production rates on Georges Bank appear to be as high as production rates of related near-shore species.
\end{abstract}

\section{INTRODUCTION}

Georges Bank, a productive fishing ground off the northeast US coast, has recently become a site for oil exploration. The Georges Bank Benthic Monitoring Program was designed to determine the fates of discharges from oil and gas exploratory operations and their effects on benthic species and communities (Maciolek-Blake et al. 1984). An understanding of natural population variability is necessary to distinguish between natural fluctuations and effects of drilling. Gammaridean amphipods, abundant over large areas of Georges Bank, are important prey of demersal fish (Langton 1983) and as such may link the possible effects of oil exploration to fish production on Georges Bank.

In this study, length-frequency analysis was used to elucidate the life histories of three amphipod species that are abundant in the areas sampled by the Benthic Monitoring Program. The 3 species are: Ampelisca agassizi (Ampeliscidae), Unciola inermis (Aoridae) and Ericthonius fasciatus (Ischyroceridae). All 3 species are tubicolous, live subtidally and are widely distributed (Bousfield 1973); little is known about their life cycles.
The species called Ericthonius fasciatus in this paper was called E. rubricornis by Bousfield in 1973 and other authors since then. The genus Ericthonius was recently revised by Myers \& McGrath (1984). Amphipods of the genus Ericthonius examined in this study fit the description of E. fasciatus by Myers \& McGrath; therefore the more recent appellation will be followed.

Ampelisca agassizi lives along both American coasts; in the northwestern Atlantic it has been collected from Nova Scotia to the Caribbean at depths of 5 to $450 \mathrm{~m}$ (Mills 1967 a). On Georges Bank, A. agassizi has been found in high densities between 60 and $170 \mathrm{~m}$ (Dickinson \& Wigley 1981). Unciola inermis is distributed along the North American Atlantic coast from Labrador to North Carolina at depths of 0 to $200 \mathrm{~m}$ (Shoemaker 1945). U. inermis inhabits the perimeter of Georges Bank between 57 and $192 \mathrm{~m}$ (Dickinson \& Wigley 1981). Ericthonius fasciatus has an amphiAtlantic distribution; along the North American coast it has been collected from Labrador to Cape Hatteras at depths of 0 to $400 \mathrm{~m}$ (Dickinson et al. 1980). E. fasciatus inhabits the perimeter of Georges Bank between 40 and $192 \mathrm{~m}$ (Dickinson \& Wigley 1981).

Steimle (in press) estimated macrofaunal production 
on Georges Bank using biomass data from two benthic surveys and production-to-biomass ratios from other areas. Results reported here are the first direct production estimates for Georges Bank benthic macrofauna. A major objective of this ongoing study is to determine the role of physical (temperature, winter storms) versus biological (food supply, predation) factors in the population dynamics of these benthic amphipod species.

\section{MATERIALS AND METHODS}

As part of the Benthic Monitoring Program, grab samples were collected on a quarterly basis from July 1981 to July 1983. Locations of regional sampling stations are shown in Fig. 1. At each station, on each sampling date, 6 replicate, $0.04 \mathrm{~m}^{2}$, modified Van Veen grab samples were collected and preserved. All replicates were taken within $140 \mathrm{~m}$ of the station coordinates. At Battelle Marine Research Laboratory, each sample was sieved on a $0.3 \mathrm{~mm}$ screen, sorted, enumerated and identified to species. Size selectivity should not be a problem here because a $0.3 \mathrm{~mm}$ sieve retains all life stages including dislodged eggs.

Regional Stations 5 and 13 were chosen for this study because fish stomachs also were collected at these sites. Station 5 at $84 \mathrm{~m}$ depth is characterized by medium-to-coarse sand. Unciola inemis and Ericthonius fasciatus are among the 5 most numerous macrofaunal species at this site. The sediments at Station 13. located at $69 \mathrm{~m}$ in the area south of Nantucket known locally as the 'mudpatch', are predominantiy very fine sand, silt and clay. Ampelisca agassizi is one of the top 5 numerically dominant species there. The sediments and fauna at these sites are described more completely by Maciolek-Blake et al. (1984).

The amphipods were measured at the Woods Hole Oceanographic Institution with a digitizer coupled to a microcomputer. Sample sizes permitting, at least 200 individuals of each species from each sampling date were digitized. Each individual was measured from the tip of the rostrum to the base of the telson (Bousfield 1973) by tracing a camera lucida projection with the digitizer wand. An internal calibration factor allowed immediate conversion from digitizer units to length in $\mathrm{mm}$.

To eliminate potential preservation bias, lengthweight relations were determined for each species using live animals collected in May 1983. Live weights were obtained by damp drying individuals and weighing to $0.01 \mathrm{mg}$ on a Mettler balance. The animals were then anaesthetized with FINQUEL before measuring. A line of the form

$$
\log (w)=a+b \log (1),
$$

(where $\mathrm{l}=$ length; $\mathrm{w}$ : weight) was fitted for each species by linear regression. Ash-free dry weight was ascertained for groups of animals with a total fresh weight of between 20 and $30 \mathrm{mg}$. Each sample was dried to constant weight at $60^{\circ} \mathrm{C}$ and combusted at $450^{\circ} \mathrm{C}$ for $5 \mathrm{~h}$ to determine ash weight.

Modal analysis was used to identify cohorts in the length-frequency data. The computer programm NORMSEP, written in FORTRAN by Tomlinson (1971)

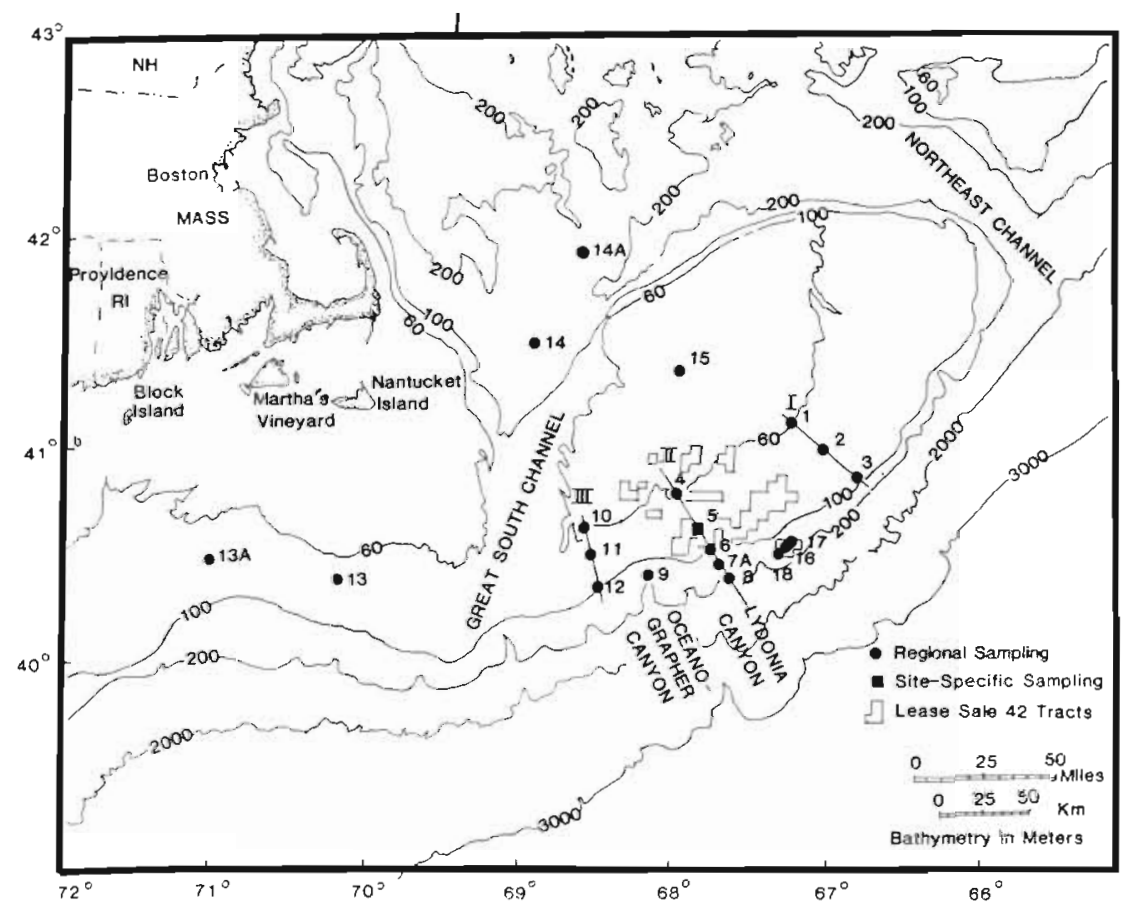

Fig. 1. Locations of stations sampled by the Georges Bank Benthic Infauna Monitoring Program 
using Hasselblad's (1966) algorithm, separates lengthfrequency sampling distributions into component normal distributions. In essence, this is a computer equivalent of the probability-paper method (Harding 1949). Apart from saving time and effort, NORMSEP is an improvement over probability paper in that a maximum-likelihood function is used to optimize the fit and a chi-square statistic measures the goodness of fit. For each component distribution NORMSEP calculates mean length, standard deviation, and number of individuals.

Growth and mortality rates were determined by following the mean length and numbers of each cohort over time. Mean length of the animals in a cohort was converted to mean weight using the length-weight regressions. Annual production was calculated by the increment-summation method described by Crisp (1984). For each cohort, production (P) is calculated as the sum of weight increments over the nine sampling dates:

$$
P=\sum_{t} \frac{N(t)+N(t+1)}{2}(\bar{w}(t+1)-\bar{w}(t))
$$

where $N(t)$ and $\bar{w}(t)=$ respectively, number and mean weight of individuals in the cohort at time $t$. Total annual production is the sum of each cohort's production.

\section{RESULTS}

Observed length-frequency distributions are plotted in Fig. $2,3 \& 4$. The frequencies are based on 6 replicate, $0.04 \mathrm{~m}^{2}$ grab samples, giving a total area of $0.24 \mathrm{~m}^{2}$. The eggs of these amphipod species develop and hatch in the marsupium formed by the females' oostegites. White blocks in the histograms represent ovigerous females. The mean size of juveniles still in the marsupium was $1.8 \mathrm{~mm}$ for Ampelisca agassizi and $1.4 \mathrm{~mm}$ for both Unciola inermis and Ericthonius fasciatus; therefore peaks in the length-frequency distributions at these lengths correspond to newly released juveniles. Cohorts are identified according to the year (and season) in which they were released.

Ampelisca agassizi at Station 13 (Fig. 2) appears to be a biennial species, in that females of a given generation breed at Age 1 and at least some survive to breed at Age 2. For example Cohorts $80 \mathrm{~A}$ and $80 \mathrm{~B}$ had ovigerous females in November 1981 and again in July 1982, while cohort $81 \mathrm{~B}$ had ovigerous females in November 1982 and again in May 1983. The timing of reproduction varied from year to year. In 1981 ovigerous females were found only in November and recruitment of juveniles occurred in the late fall. Recruitment was delayed in 1981 because cohort 79 did not survive to breed for a second year. In 1982 the breeding season

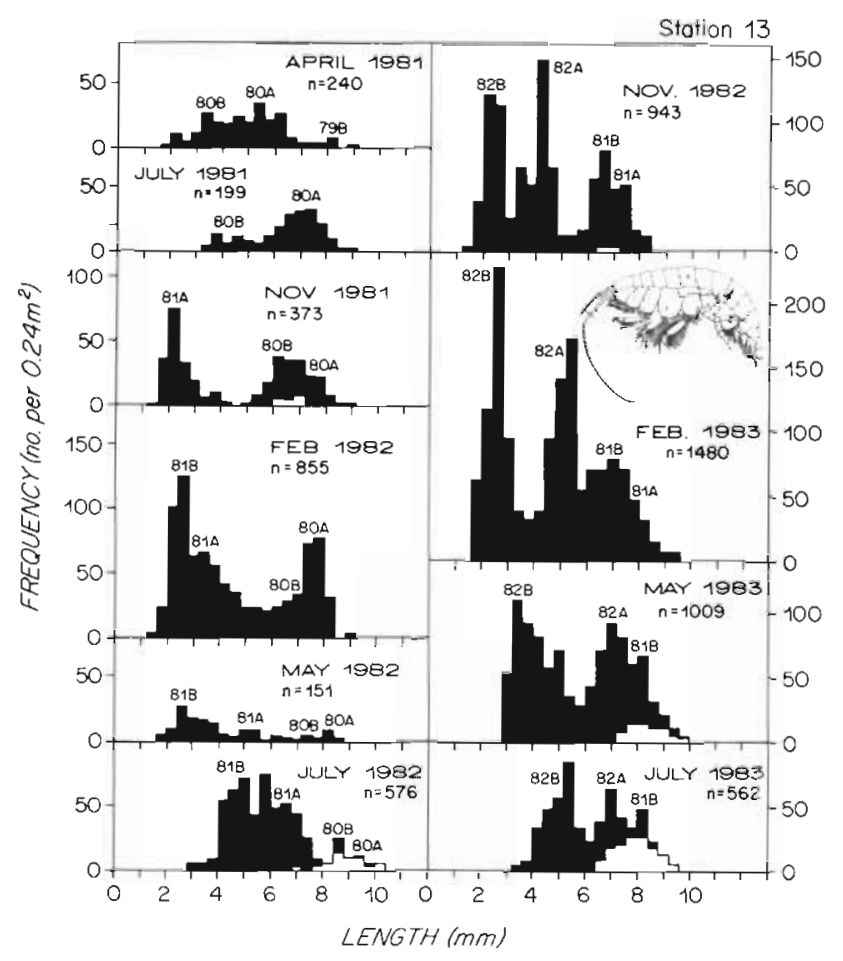

Fig. 2. Ampelisca agassizi. Length-frequency at Station 13. White blocks in the histograms represent ovigerous females

was advanced with ovigerous females present in July and November and recruitment in the late summer. The breeding season was even more advanced in 1983 with ovigerous females present in May and July. Recruitment of juveniles had not occurred by July suggesting that either juveniles were released and lost from the sampling area or the development time of embryos is longer than 2 mo. The minimum and maximum lengths of ovigerous females were 5.4 and $10.1 \mathrm{~mm}$ respectively. A length of $10 \mathrm{~mm}$ may be reached after the maximum life-span of $2 \mathrm{yr}$.

Unciola inermis at Station 5 (Fig. 3) is an annual species with ovigerous females present in February and May (a few in July 1983) and recruitment of juveniles in May. A length of $11 \mathrm{~mm}$ may be reached after the maximum life-span of about $1.5 \mathrm{yr}$. The minimum and maximum lengths of ovigerous females were 5.0 and $10.5 \mathrm{~mm}$. A few individuals may survive for a second year (e.g. Cohort 81B).

At the same station, ovigerous females of Ericthonius fasciatus (Fig. 4) were present throughout the year but recruitment of juveniles was concentrated during the spring and fall, resulting in 2 generations per year. A striking feature of the distribution of E. fasciatus at this station is its virtual disappearance in February 1982 and subsequent recolonization in May. The reasons for this disappearance and the source of colonists will be discussed below. Individuals of the spring generation 


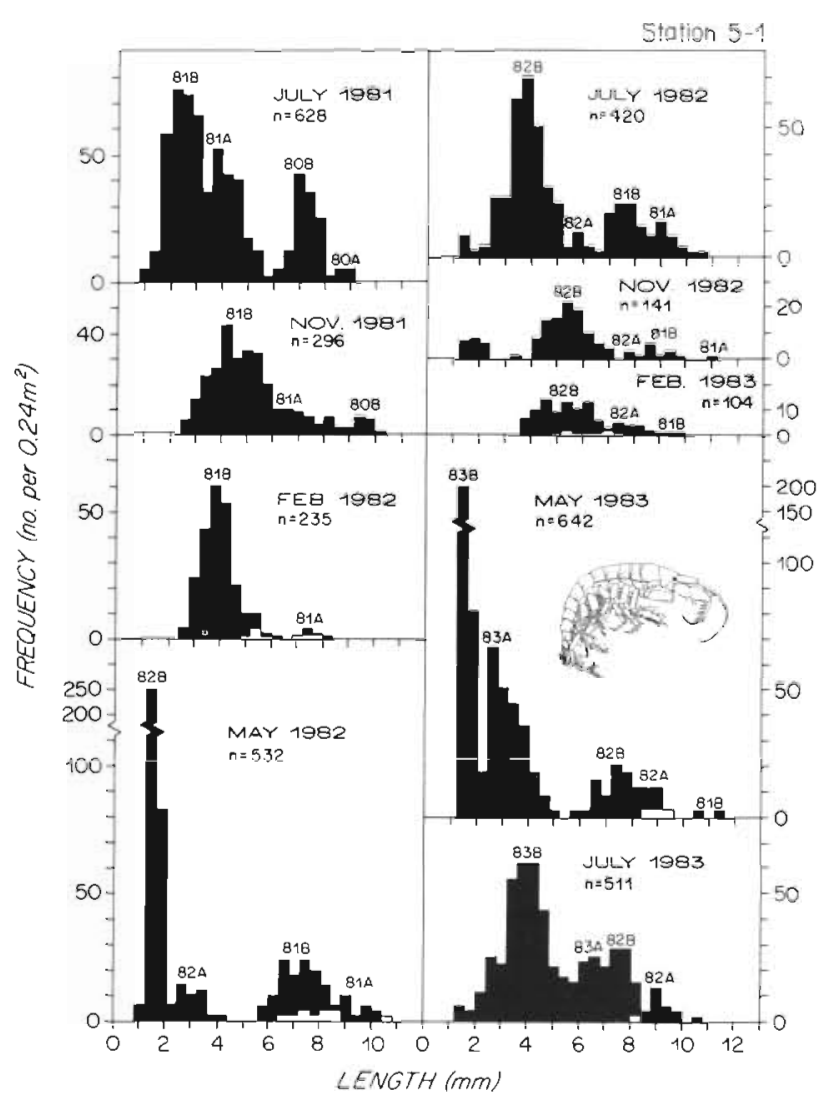

Fig. 3. Unciola inermis. Length-frequency at Station 5-1 White blocks in the histograms represent ovigerous females

may reach a maximum length of $7 \mathrm{~mm}$ in 6 mo while those of the fall generation may reach a maximum of $9 \mathrm{~mm}$ in $8 \mathrm{mo}$. Minimum and maximum lengths of ovigerous females were 4.8 and $8.4 \mathrm{~mm}$ respectively.

In all 3 species, each generation appears to be composed of 2 modes (these cohorts are labeled A and B in Fig. 2, 3 \& 4). Bimodality is more distinct for Unciola inermis and Ampelisca agassizi because their reproduction is more highly synchronous than that of Ericthonius fasciatus. A and $\mathrm{B}$ cohorts are apparent for $E$. fasciatus in July but are less obvious at other times of the year.

To test whether these $\mathrm{A}$ and $\mathrm{B}$ cohorts are true modes, NORMSEP was run assuming either 1 or 2 modes per generation. In almost all cases, a better fit was obtained with 2 modes per generation. A and B cohorts were more difficult to separate for adults because variability in individual growth rates obscures the modes with time. Fig. 5 is an example using NORMSEP to fit the length-frequency distribution of Unciola inermis in July 1981.

Comparing between years, the length-frequency distributions for the same months (e.g. Jul $1981 \mathrm{com}$ pared to Jul 1982 and Jul 1983), the positions of the modes are quite similar. This is true for all 3 species

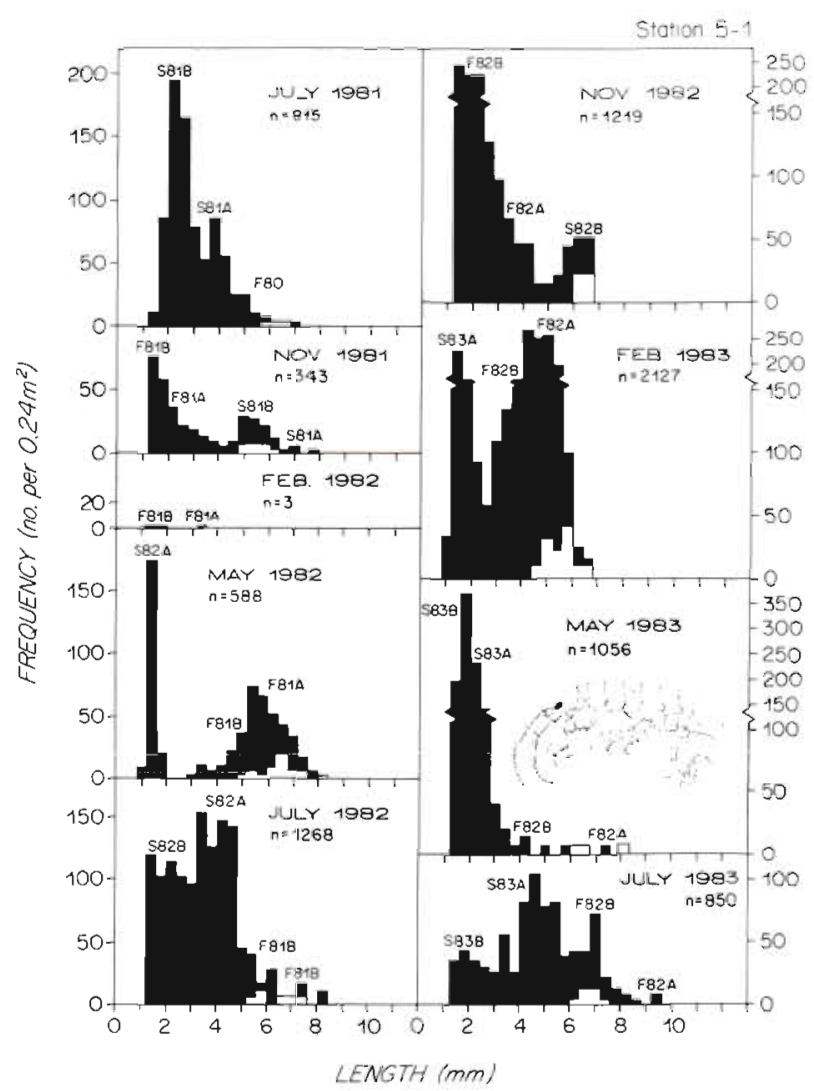

Fig. 4. Ericthonius fasciatus. Length-frequency at Station 5-1. White blocks in the histograms represent ovigerous females

and it indicates a strong seasonal influence. On the other hand, the total number of individuals varies considerably from year to year, suggesting that other factors in addition to the seasonal cycle affect the distribution and abundance of these amphipods.

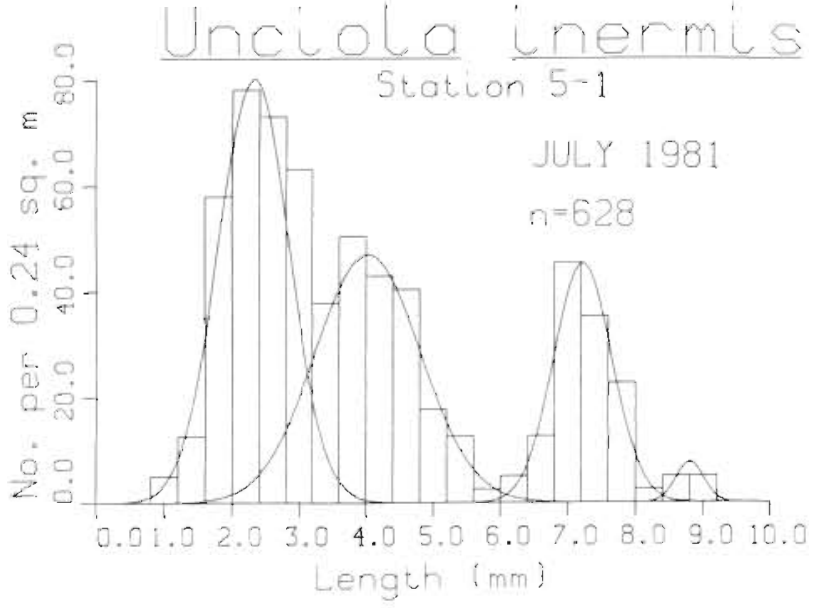

Fig. 5. Example using computer program NORMSEP to tit normal curves to the observed length-frequency distribution. The chi-square of 4.6 with 8 degrees of freedom gives a probability of 0.8 that the observed distribution was drawn from a group of normal distributions described by the given parameters 
Growth curves for each cohort are shown in Fig. 6. The vertical bars equal 2 standard deviations as estimated by NORMSEP. Where vertical bars overlap, the modes are indistinct. A common feature of all 3 species is that the growth rate decreases in the winter (for Unciola inermis, Cohort $81 \mathrm{~B}$ and $82 \mathrm{~B}$, the mean length actually decreased between Feb and May) as well as with age. Ericthonius fasciatus has the fastest growth rate (max $1 \mathrm{~mm} \mathrm{mo}^{-1}$ ) with $U$. inermis intermediate and Ampelisca agassizi the slowest. This is consistent with their respective life-spans.

Length-weight relations are plotted in Fig. 7. Despite the inherent variability of wet weights, a significant fit was obtained for each species by using a

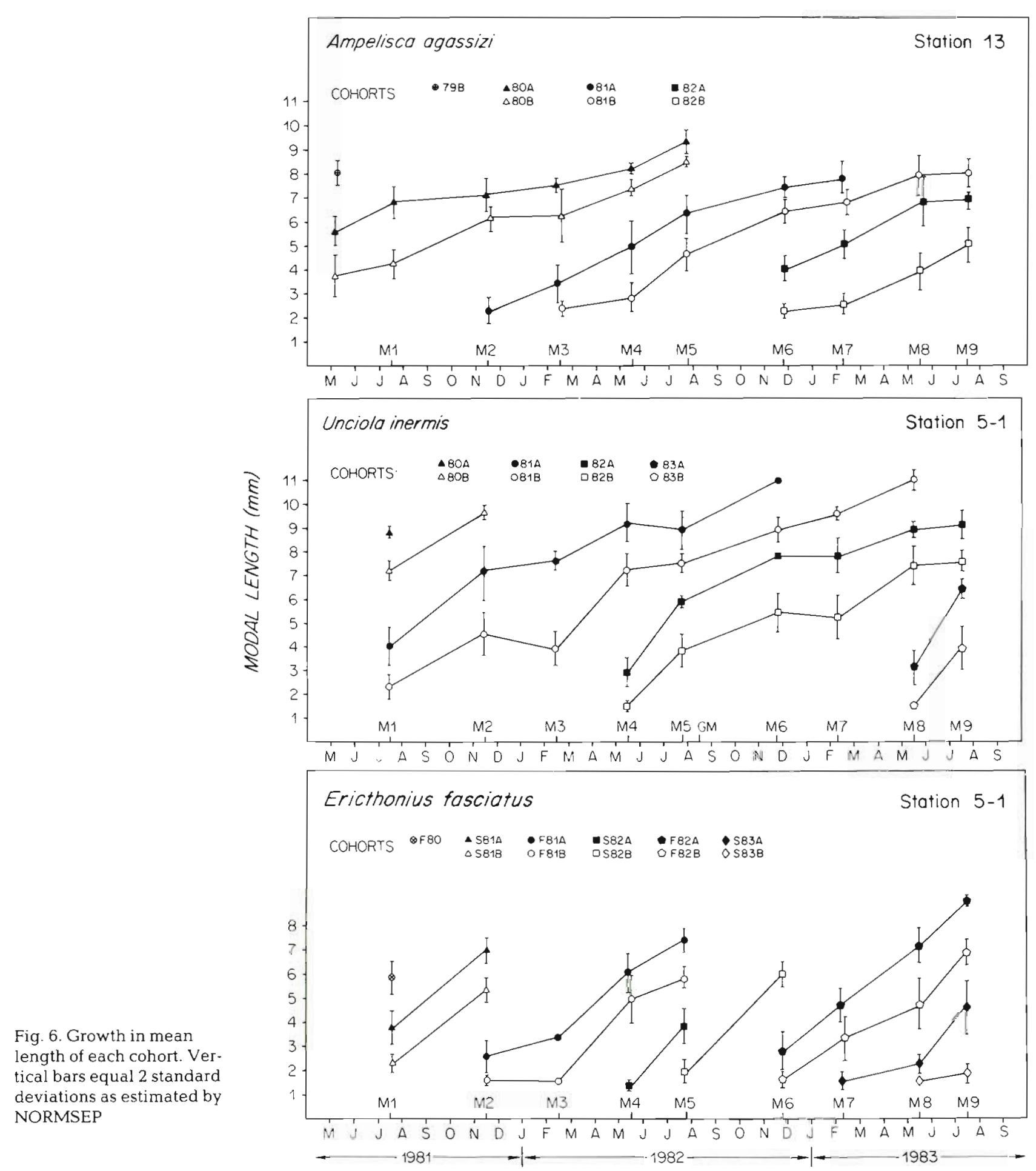



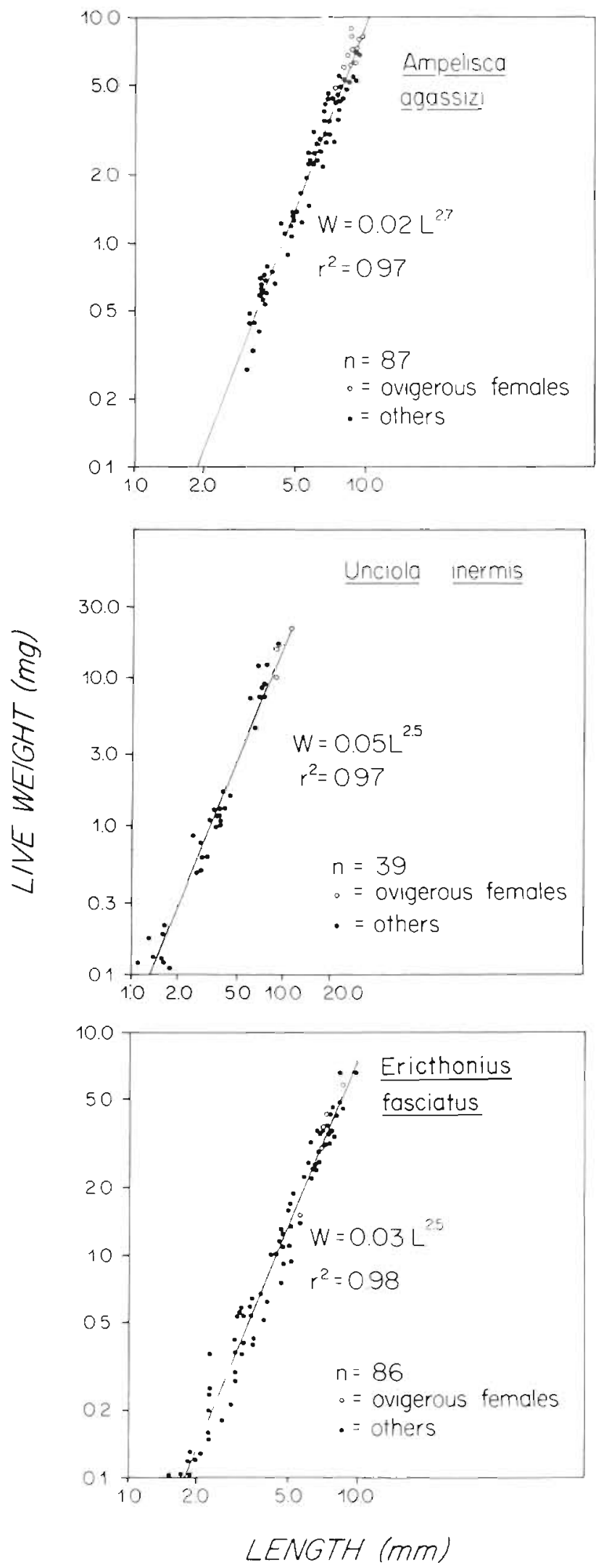

Fig. 7. Length-weight relations as fitted by linear least squares
Table 1. Ash-free dry weight determination

\begin{tabular}{|c|c|c|c|}
\hline n (groups) & $\begin{array}{c}\text { Ampelisca } \\
\text { agassizi } \\
3\end{array}$ & $\begin{array}{c}\text { Unciola } \\
\text { inermis } \\
3\end{array}$ & $\begin{array}{c}\text { Ericthonius } \\
\text { fasciatus } \\
4\end{array}$ \\
\hline$\%$ water & 75.9 & 74.4 & 80.9 \\
\hline$\%$ ash & 7.1 & 8.5 & 6.1 \\
\hline $\begin{array}{l}\% \text { ash-free } \\
\text { dry weight }\end{array}$ & 17.0 & 17.1 & 13.0 \\
\hline
\end{tabular}

relatively large sample size. For all 3 species, the regression coefficient (b) is significantly less than 3. This indicates that growth in weight is not isometric; weight increases less rapidly than does length.

Table 1 summarizes the ash-free dry weight determinations. Compared to the other 2 species, Ericthonius fasciatus not only has a lower weight for a given length, it also has a higher percentage of water. This could explain how it grows faster than do the other 2 species - by producing less dry weight per unit length.

Production and biomass estimates are listed in Table 2. Comparing the 2 years, the $\mathrm{P} / \mathrm{B}$ ratios varied much less than did production and biomass. The maximum change in $\mathrm{P} / \mathrm{B}$ was a $20 \%$ decrease for Unciola inermis while production and biomass changed by as much as 2.5 fold. Interannual differences in $\mathrm{P} / \mathrm{B}$ were also less than the differences between species. Ericthonius fasciatus had the highest $\mathrm{P} / \mathrm{B}$ ratio followed by $U$. inermis and Ampelisca agassizi.

Table 3 compares a number of life-history traits of the 3 species. The coefficient of variation of sample means is a measure of the patchiness of the species distribution relative to the size of the grab and the area over which the replicates were taken. Thus Ericthonius faciatus is the most patchily distributed and Ampelisca agassizi the least so. Fish predation data are based on

Table 2. Biomass and production estimates ( $g d w=g d r y$ weight)

\begin{tabular}{|c|c|c|c|}
\hline & $\begin{array}{c}\text { Ampelisca } \\
\text { agassizi }\end{array}$ & $\begin{array}{l}\text { Unciola } \\
\text { inermis }\end{array}$ & $\begin{array}{c}\text { Ericthonius } \\
\text { fasciatus }\end{array}$ \\
\hline \multicolumn{4}{|c|}{ Production $\left(g d w \mathrm{~m}^{-2} \mathrm{yr}^{-1}\right)$} \\
\hline Jul 81-Jul 82 & 1.28 & 3.11 & 1.42 \\
\hline Jul $82-J u l ~ 83$ & 3.21 & 2.47 & 3.13 \\
\hline Jul 81-Jul 83 (mean) & 2.24 & 2.79 & 2.28 \\
\hline \multicolumn{4}{|l|}{ Mean biomass ( $\mathrm{gdw} \mathrm{m}^{-2}$ ) } \\
\hline Jul $81-$ Jul 82 & 0.92 & 1.18 & 0.31 \\
\hline Jul 82-Jul 83 & 1.99 & 1.16 & 0.76 \\
\hline Jul $81-J u l ~ 83$ & 1.46 & 1.12 & 0.52 \\
\hline \multicolumn{4}{|l|}{$\mathrm{P} / \mathrm{B}(1 / \mathrm{y})$} \\
\hline Jul 81-Jul 82 & 1.4 & 2.6 & 4.6 \\
\hline Jul 82-Jul 83 & 1.6 & 2.1 & 4.1 \\
\hline Jul $81-J u i ~ 83$ & 1.5 & 2.5 & 4.4 \\
\hline
\end{tabular}


Table 3. Summary of life-history traits ( $\mathrm{CV}=$ coefficient of variation)

\begin{tabular}{lccc|}
\hline Traits & A. agassizi & U. inermis & E. fasciatus \\
\hline Generation time & Biennial & Annual & Semi-annual \\
P/B (1/yr) & 1.5 & 2.5 & 4.4 \\
CV of sample means & 40.5 & 54.8 & 83.8 \\
Mean per fish stomach & 15.0 & 72.4 & 88.4 \\
Sediment affinity & Fine sand & Medium sand & Shell fragments \\
\hline
\end{tabular}

analysis of yellowtail flounder stomachs collected at the same stations (Maciolek-Blake et al. 1984). It should be stressed that results given here measure the mean number of prey per predator, not the predation rate. Nonetheless, these data suggest that flounder eat $E$. fasciatus most often and $A$. agassizi least often.

\section{DISCUSSION}

The method of length-frequency analysis employed in this study depends critically on the ability to distinguish cohorts and to follow them through time. The 3 amphipod species considered here lend themselves to this type of analysis because they are relatively shortlived and generations are separable.

Bimodal recruitment has been observed in other amphipod species by other authors. Mills (1967b) found bimodality in both winter and summer generations of Ampelisca abdita. Since the time difference between modes as estimated from the growth curve is about $28 \mathrm{~d}$, Mills suggested that breeding may somehow be linked to the lunar cycle. Corophium volutator, studied by Moller \& Rosenberg (1982), has a life history similar to $A$, abdita. Winter and summer generations are both bimodal and, judging by the author's Fig. 4 , these cohorts are released approximately one month apart. A. tenuicornis collected off the northeast coast of England (Sheader 1977) also exhibited bimodal generations. Sheader suggested that this recruitment pattern resulted from the simultaneous onset of breeding and the synchronous production of a second brood by a proportion of the females. The following spring the first brood matured earlier than the second, thus reinforcing the double peak of recruitment. In summary, bimodal recruitment is common in amphipods and the most likely cause is multiple broods reinforced by the second brood maturing later.

In the 3 amphipod species studied here, the cue for the onset of breeding is not apparent since ovigerous females of at least 1 species were present during all seasons of the year. If there is an environmental cue it probably is not the same for all 3 species. Onset of breeding is a function of length in that the cohorts mature sequentially with the largest females maturing first. This tends to reinforce the bimodal recruitment but probably is not enough, in itself, to maintain the pattern.

Compelling evidence for multiple broods would be to find ovigerous females which also have developing oocytes in their ovaries; such females could potentially have 2 broods. In this study, some cohorts had ovigerous females on 2 consecutive cruises, suggesting that multiple broods are possible. However, the development time for embryos of these species is not known. In developing females the ovaries were clearly visible but none of the ovigerous females observed also had developing oocytes.

Frequency of sampling was dictated by the Benthic Monitoring Program and thus could not be controlled in this study. While more frequent sampling would increase the precision of the production estimates, I do not think any reproductive events were missed by the present sampling regime. My estimates do not account for the production of a cohort before the first date or after the last date it appears in the samples. This underestimate is expected to be small compared with the total production of the cohort over its life-span because, in the first case the mean weight of individuals is small, while in the latter case the numbers are few.

To estimate the maximum potential production underestimate I made the following assumptions. For a juvenile cohort first sampled at $Q(t)$, I assumed that the entire cohort recruited immediately following the sampling date $\mathrm{Q}(\mathrm{t}-1)$ when the cohort was not present. The lengths of these recruits were assumed to be the same as the lengths of newly recruited juveniles of each species. For adult cohorts which disappear following $Q(t)$, I assumed that the entire cohort lived until immediately before the next sampling date $Q(t+1)$ and that the mean length was equal to the greatest mean length observed for that species.

Using these assumptions I recalculated production for the $2 \mathrm{yr}$ period. Maximum potential production underestimates were $7.2 \%$ for Unciola inermis, $17.2 \%$ for Ampelisca agassizi and $50 \%$ for Ericthonius fasciatus. The potential underestimate for $U$. inermis is probably smaller than errors from other causes. For A. agassizi the potential underestimate is largely 
Table 4. Annual production estimates of marine gammaridean amphipods ( $g d w=g$ dry weight)

\begin{tabular}{|c|c|c|c|c|}
\hline Species & $\begin{array}{l}\text { Location and depth } \\
\qquad(\mathrm{m})\end{array}$ & $\begin{array}{l}\text { Production } \\
\left(\text { gdw } \mathrm{m}^{-2} \mathrm{yr}^{-1}\right)\end{array}$ & $\begin{array}{l}\mathrm{P} / \mathrm{B} \\
(1 / \mathrm{yr})\end{array}$ & Reference \\
\hline Ampelisca tenuicornis & North Sea (58) & $0.2^{\circ}$ & 3.4 & Sheader (1977) \\
\hline A brevicornis & North Sea $(28)$ & $1.0^{\circ}$ & 4.0 & Klein et al. (1975) \\
\hline A. brevicornis & Isle of Man (intertidal) & $1.3-1.7$ & $2.5-3.2$ & Hastings (1981) \\
\hline A. spinipes & Coast of Brittany (17) & 0.2 & 2.4 & Glemarec \& Menesguen (1980) \\
\hline A. araucana & Coast of Chile (65) & $5.8 \cdots$ & $1.9^{\cdots}$ & Carrasco \& Arcos $(1984)$ \\
\hline A. agassizi & Georges Bank (68) & 2.2 & 1.5 & This study \\
\hline Corophium insidiosum & Swedish coast (intertidal) & $\begin{array}{c}0.2-8 \\
\text { (May-Sep) }\end{array}$ & $2-5$ & Birklund (1977) \\
\hline C. volutator & Swedish coast (intertidal) & $\begin{array}{c}2-4 \\
\text { (May-Sep) }\end{array}$ & $3-4$ & Birklund (1977) \\
\hline C. volutator & Swedish coast (intertidal) & $1.5-30^{\circ}$ & $5.1-11.3$ & Moller \& Rosenberg (1982) \\
\hline Ericthonius fasciatus & Georges Bank $(84)$ & 2.3 & 4.4 & This study \\
\hline Unicola inermis & Georges Bank (84) & 2.8 & 2.5 & This study \\
\hline Pontoporeia affinis & Baltic Sea $\{46\}$ & 3.2 & 1.9 & Cederwall (1977) \\
\hline P. femorata & Baltic Sea $(46)$ & 3.0 & 1.4 & Cederwall (1977) \\
\hline P. femorata & Nova Scotia $(4-10)$ & $2.8-3.5^{\circ}$ & $3.6-4.8$ & Wildish \& Peer (1981) \\
\hline
\end{tabular}

accounted for by the disappearance of the $81 \mathrm{~A}$ cohort after February 1983 and the 82A cohort not appearing in the samples until a mean length of $4 \mathrm{~mm}$. The large potential underestimate for $E$. fasciatus is mostly due to the untimely disappearance of Cohort S82A after July 1982. Assumptions used here are for the worst-case scenario; the actual production underestimates are almost certainly less than those calculated here. For annual species, quarterly sampling is probably adequate; for semi-annual species more frequent sampling (e.g. every $2 \mathrm{mo}$ ) is desirable.

Errors in estimating the number of animals in each cohort could result from migration, patchiness in species distribution, variation in sampling efficiency (e.g. due to sea state), or from operation of the computer program NORMSEP. Since it is not always possible to distinguish these sources of error, I shall merely discuss the most glaring numerical inconsistencies. The total number of Ampelisca agassizi decreased sharply in May 1982 and then increased in July 1982 even though there was no recruitment during this period. Of the 3 species considered here, A. agassizi is the least patchy and least mobile, suggesting that this is a sampling problem. In May 1982, when the performance of the grab was greatly reduced due to heavy seas, other species in the same grab samples also declined in abundance. One year later, in May 1983, $A$. agassizi was more than 5 times more abundant at Station 13, implying that the decline seen in 1982 was not a seasonal phenomenon.
On the other hand, the virtual disappearance of Ericthonius fasciatus in February 1982 does not seem to be a sampling problem because Unciola inermis persisted in the same grabs. Reappearance of E. fasciatus in May 1982 was probably due to colonization by adults from adjacent areas where this species had remained abundant. The following February E. fasciatus reached its highest density. In a population open to migration, production is lost and gained to and from other areas. Therefore, production as estimated here does not apply to a closed population but instead applies to the area of sea bottom over which the samples were taken.

Despite the qualifications mentioned above, these are the first direct production estimates for benthic macrofaunal species on Georges Bank. Table 4 lists production estimates for different species of marine amphipods at different locations. For ease of comparison all production rates are given in units of grams dry weight $\mathrm{m}^{-2} \mathrm{yr}^{-1}$. Where the appropriate conversion factor was not given by the author(s), I used my percent-composition data from Table 1. The data for Ampelisca agassizi were used for all ampeliscids, Ericthonius fasciatus data for Corophium and, for lack of a confamilial species, Unciola inermis data for Pontoporeia.

Despite having a lower P/B ratio than the other ampeliscids, Ampelisca agassizi has an intermediate production rate by virtue of its higher mean biomass. Since Unciola inermis and Ericthonius fasciatus are in 
the superfamily Corophioidae, they should be compared to the 2 species of Corophium. Production of $U$. inermis and E. fasciatus is within the range of estimates for the two intertidal corophid species. Apparently, amphipod production on Georges Bank is as high as production by related near-shore species.

Comparison of the life-history strategies of the 3 amphipod species (Table 3) yields a consistent pattern. Ampelisca agassizi is mainly a deposit feeder on fine sediments in weak currents; its tube extends vertically in the substratum, providing a refuge from fish predation. Of the 3 species, $A$. agassizi has the slowest growth, lowest mortality and is eaten less by flounder. The low turnover rate and less patchy distribution could be related to this species' affinity for finer sediments at greater depths where the sediments presumably are disturbed less frequently. In contrast, Ericthonius fasciatus is an epifaunal tube builder, living in stronger currents, perhaps mainly as a filter feeder. $E$. fasciatus has the fastest growth, highest mortality and is eaten more by flounder. The high turnover rate and patchier distribution of this species may be related to its affinity for coarser sediments at shallower depths where sediment resuspension is presumably more frequent. Unciola inermis is intermediate in these traits.

Results of this study have implications for pollution monitoring. Most of the observed variation in amphipod numbers can be accounted for by recruitment and subsequent mortality. The observation that $\mathrm{P} / \mathrm{B}$ ratios varied less than did density, biomass and production suggests that this ratio may be useful in monitoring the effects of pollution on marine communities. Using this method, it is presently not possible to say whether $2 \mathrm{P} / \mathrm{B}$ ratios are statistically different. A means of estimating confidence intervals for the production estimates is needed.

Acknowledgements. This study would not have been possible without the help and cooperation of many people. In particular I thank Dr. J. F. Grassle, Rose Petrecca and Dr. N. Maciolek-Blake for their help in planning, sample collection and analysis respectively. Elizabeth Miller typed and edited the first draft; Drs Craig Smith, Howard L. Sanders and 2 anonymous reviewers provided valuable criticism of subsequent drafts. The amphipod drawings in Fig. $2 \& 4$ are from E. L. Bousfield: Shallow-water Gammaridean Amphipoda of New England, Copyright (c) 1973 by the National Museums of Canada and used by permission of the publisher, Cornell University Press. The amphipod drawing used in Fig. 3 was redrawn from Shoemaker (1945). This work was funded by Contract no. 14-12-001-29192 from the Minerals Management Service, USDI. Contribution number 5762 from the Woods Hole Oceanographic Institution.

\section{LITERATURE CITED}

Birklund, J. (1977). Biomass, growth and production of the amphipod Corophium insidiosum (Crawford) and preliminary notes on Corophium volutator (Pallas). Ophelia 16: $187-203$

Bousfield, E. L. (1973). Shallow-water Gammaridean Amphipoda of New England. Cornell University Press, Ithica, New York

Carrasco, F. D., Arcos, D. F. (1984). Life history and production of a cold temperate population of the sublittoral amphipod Ampelisca araucana. Mar. Ecol. Prog. Ser, 14: $245-252$

Cederwall, $H$. (1977). Annual macrofauna production of a soft bottom in the northern Baltic proper. In: Keegan, B. F., O Ceidigh, P., Boaden, P. S. S. (ed.) Biology of benthic organisms. Pergamon Press, Oxford, p. 155-164

Crisp, D. J. (1984). Energy flow measurements. In: Holm, N. A., McIntyre, A. D. (ed.) Methods for the study of marine benthos, 2nd ed. IBP Handbook No. 16. Blackwell, Oxford, p. $284-372$

Dickinson, J. J., Wigley, R. L., Brodeur, R. D., Brown-Leger, S. (1980). Distribution of Gammaridean Amphipoda (Crustacea) in the middle Atlantic bight region. U.S. Dep. Comm., NOAA Tech. Rep. NMFS SSRF-741

Dickinson, J. J., Wigley, R. L. (1981). Distribution of Gammaridean Amphipoda (Crustacea) on Georges Bank. U.S. Dep. Comm., NOAA Tech. Rep. NMFS SSRF-746

Glemarec, M. A., Menesguen, A. (1980). Functioning of a muddy sand ecosystem: seasonal fluctuations of different trophic levels of the dominant macrofaunal species. In: Tenore, K. R., Coull, B. C. (ed.) Marine benthic dynamics. University of South Carolina Press, Columbia, South Carolina, p. 49-68

Harding, J. P. (1949). The use of probability paper for the graphical analysis of polymodal frequency distributions. J. mar. biol. Ass. U.K. 28: 141-153

Hasselblad, V. (1966). Estimation of parameters for a mixture of normal distributions. Technometrics 8: 431-444

Hastings, M. H. (1981). The life cycle and productivity of an intertidal population of the amphipod Ampelisca brevicornis. Estuar. coast. Shelf Sci. 12: 665-677

Klein, G., Rachor, E., Gerlach, S. A. (1975). Dynamics and productivity of two populations of the benthic tube-dwelling amphipod Ampelisca brevicornis (Costa) in Helgoland Bight. Ophelia 14: 139-159

Langton, R. W. (1983). Food habits of yellowtail flounder, Limanda ferruginea (Storer), from off the northeastern United States, Fish. Bull. U.S. 81: 15-22

Maciolek-Blake, N., Grassle, J. F., Blake, J. A., Neff, J. M. (1984). Georges Bank benthic infauna monitoring program. Final Report, Year 2 to US Dept. of the Interior, Minerals Management Service, Washington D.C. Battelle and Woods Hole Oceanographic Institution

Mills, E. L. (1967a). A reexamination of some species of Ampelisca (Crustacea: Amphipoda) from the east coast of North America. Can. J. Zool. 45: 635-652

Mills, E. L. (1967b). The biology of an ampeliscid amphipod crustacean sibling species pair. J. Fish. Res. Bd Can. 24: 305-355

Moller, P., Rosenberg, R. (1982). Production and abundance of the amphipod Corophium volutator on the west coast of Sweden. Neth. J. Sea Res. 16: 127-140

Myers, A. A., McGrath, D. (1984). A revision of the northeast Atlantic species of Ericthonius (Crustacea: Amphipoda). J. mar. biol. Ass. U.K. 64: 379-400

Sheader, M. (1977). Production and population dynamics of 
Ampelisca tenuicornis (Amphipoda) with notes on the biology of its parasite Sphaeronella longipes (Copepoda). J. mar. biol. Ass. U.K. 57: 955-968

Shoemaker, C. R. (1945). The amphipod genus Unciola on the east coast of America. Am. Midl. Nat. 34: 446-465

Steimle, F. (in press). Benthic faunal production. In: Backus, R. H. (ed.) Georges Bank. MIT Press, Cambridge, Mass.
Tomlinson, P. K. (1971). NORMSEP: normal distribution separation. In: Abramson, N. J. (ed.) Computer programs for fish stock assessment. FAO Fish. Tech. Pap. 101 (FIRD/ T101) FAO, Rome

Wildish, D. J., Peer, D. (1981). Methods for estimating secondary production in marine amphipoda. Can. J. Fish. aquat. Sci. 38: 1019-1026

This paper was presented by Dr. R. Scheltema; it was accepted for printing on January 11, 1985 